\title{
Antinociceptive, Anti-Inflammatory, and Antipyretic Activity of Mangrove Plants: A Mini Review
}

\author{
J. A. Shilpi, ${ }^{1}$ M. E. Islam, ${ }^{2}$ M. Billah, ${ }^{2}$ K. M. D. Islam, ${ }^{2}$ F. Sabrin, ${ }^{3}$ S. J. Uddin, ${ }^{4}$ \\ L. Nahar, ${ }^{5}$ and S. D. Sarker ${ }^{6}$ \\ ${ }^{1}$ Pharmacy Discipline, Khulna University, Khulna 9208, Bangladesh \\ ${ }^{2}$ Biotechnology and Genetics Discipline, Khulna University, Khulna 9208, Bangladesh \\ ${ }^{3}$ Department of Biotechnology and Genetic Engineering, Mawlana Bhashani Science and Technology University, \\ Santosh, Tangail 1902, Bangladesh \\ ${ }^{4}$ School of Pharmacy, Griffith University, QLD 4222, Australia \\ ${ }^{5}$ Leicester School of Pharmacy, De Montfort University, The Gateway, Leicester LE1 9BH, UK \\ ${ }^{6}$ Department of Pharmacy, School of Applied Sciences, University of Wolverhampton, MA Building, \\ Wulfruna Street, Wolverhampton WV1 1LY, UK \\ Correspondence should be addressed to S. D. Sarker, s.sarker@wlv.ac.uk
}

Received 31 January 2012; Accepted 16 February 2012

Academic Editor: Esra Küpeli Akkol

Copyright () 2012 J. A. Shilpi et al. This is an open access article distributed under the Creative Commons Attribution License, which permits unrestricted use, distribution, and reproduction in any medium, provided the original work is properly cited.

Mangrove plants are specialised plants that grow in the tidal coasts of tropic and subtropic regions of the world. Their unique ecology and traditional medicinal uses of mangrove plants have attracted the attention of researchers over the years, and as a result, reports on biological activity of mangrove plants have increased significantly in recent years. This review has been set out to compile and appraise the results on antinociceptive, anti-inflammatory, and antipyretic activity of mangrove plants. While the Web of Knowledge, Google Scholar, and PubMed were the starting points to gather information, other pieces of relevant published literature were also adequately explored for this purpose. A total of 29 reports on 17 plant species have been found to report such activities. While 19 reports were on the biological activity of the crude extracts, 10 reports identified the active compound(s) of various chemical classes of natural products including terpenes, steroids, and flavonoids. This review finds that antinociceptive, anti-inflammatory, and antipyretic activity appears to be widespread in mangrove plants.

\section{Introduction}

Mangrove forests are a special type of vegetation found in the coastal regions of the tropical and subtropical parts of the world. Global area that comprises mangrove forest is about 181000 square $\mathrm{km}$. Majority of the mangrove forests is confined to the South East Asia and Australia, which accounts for $43 \%$ of the worldwide mangrove area (Table 1) $[1,2]$. About 70 plant species of 27 genera have been reported from mangrove forests [2]. However, it should be noted that mangrove forests generally support the growth of nonmangrove plant species as well. For example, 334 plant species of 245 genera have been reported so far from the Sundarbans [3]. Flora of mangrove forests is unique from others in that their habitat extends along the border where the fresh and sea water merge. Therefore, unlike common terrestrial plants, they can withstand high salt concentration, can remain submerged in water, and maintain an efficient nutrient retention mechanism [1].

Mangrove forests are still quite unfamiliar to a vast population due to their limited distribution. However, the people inhabiting areas near mangrove forests heavily depend on these forests to meet their needs including their healthcare. During the early stage of human civilization, mangrove forests drew very little or no attention. This is to some extent because of the difficulty to access these areas. As the population continued to grow, people had to find new and unexplored sources including mangrove forests. In some parts of the world, mangrove forests are over utilised. As a result, human establishment grew in close proximity of 
TABLE 1: Distribution of major mangrove forests around the world [2].

\begin{tabular}{ll}
\hline Region & Country \\
\hline \multirow{2}{*}{$\begin{array}{l}\text { South and South East Asia } \\
\text { Middle East }\end{array}$} & $\begin{array}{l}\text { The Sundarbans, Bangladesh and India; Pichavaram, India; Balochistan, Pakistan; Estuarine } \\
\text { mangroves, Thailand; Srilanka; The Philippines; East China, Taiwan; Japan; Malaysia; Borneo, Java and } \\
\text { Eastern Indonesia }\end{array}$ \\
$\begin{array}{l}\text { Australasia } \\
\text { North and South America } \\
\text { and the Caribbean }\end{array}$ & $\begin{array}{l}\text { Western and Eastern Australia; South Pacific Islands; Papua New Guinea; Solomons Island } \\
\text { Africa }\end{array}$ \\
& $\begin{array}{l}\text { Forth West of Africa stretching from Mauritania to Sierra Leone; West of Africa from Liberia to } \\
\text { Nigeria; South West Africa from Nigeria to Angola; East of Africa from Somalia to Tanzania; } \\
\text { Mozambique; Madagascar and South Africa }\end{array}$ \\
\hline
\end{tabular}

these forests. For example, the density of population near the Sundarbans is as high as $>500$ per sq km [2]. Most of these people are directly or indirectly rely on the Sundarbans for their livelihood. In addition, natural disasters are putting these forests under the threat of extinction. For example, the mangrove forest in Tamil Nadu State of India was declared Reserve forests in 1880 , but its protection ultimately failed $[2]$.

Like other terrestrial plants, many mangrove plants have ethnopharmacological relevance and have also been exploited by the local people in the search for remedies for various ailments. However, only a few of the mangrove plants have so far been included in any books listing medicinal plants. This may be due to the difficulty in collecting and identifying these plant species and lack of adequate information available about their uses. As a part of our INSPIRE Project, funded by the British Council, a recent visit to the Sundarbans and subsequent interviews with people living nearby villages have revealed that the local people use a number of plants from the Sundarbans to treat various medical conditions.

With the introduction of rapid and reliable screening methods, researchers around the world have picked plant species of various origins including mangrove plants in the search for new medicine. This review aims to compile and appraise reports on the antinociceptive, anti-inflammatory, and antipyretic activity of mangrove plants.

\section{Methodology}

Web of knowledge, Google Scholar, and PubMed were used to search for the published reports since 1950. Other relevant publications, for example, books and journal articles, were also consulted. A total of 57 mangrove species were searched for the activity. The results are presented in three different tables; Table 2 gives a general outline of works that have been carried out so far on various mangrove plants for antinociceptive, anti-inflammatory, and antipyretic activity. It also describes the plant species, family, plant part used for the investigation, reported activity, and the screening method. Table 3 deals with those reports reporting the identification of active compound(s).

\section{Antinociceptive, Anti-Inflammatory, and Antipyretic Activity}

From the search, 29 hits were found with different mangrove species reporting one or more of these activities: antinociceptive, anti-inlfammatory, and antipyretic activity (Tables 2 and 3) [4-32]. Some of the reports coincide for a given species, and, therefore, a total of 17 plants were reported to have such activity. However, only one plant, Pongamia pinnata was studied for antipyretic activity. In nine cases, further phytochemical studies were carried out to find out the active constituent(s). One of the studies justified that the activity might be due to betulinic acid since betulinic acid is known for its anti-inflammatory activity and was present in the extract [8]. According to chemical classification, the active compounds, isolated from the mangrove plants, can be classified into diterpenes [11, 15], flavonoids [24], isoflavonoids [25, 29], monoterpenes [30], phenolics [30], steroids [32], triterpenes [29], xanthones [14], and a compound with unidentified structure [13] (Table 3).

The diterpenoids reported by Yodsaoue et al. [11] from the root extract of Caesalpinia mimosoides showed anti-inflammatory activity in micromolar range. The most potent activity was observed with mimosol D (Figure 1), which showed an $\mathrm{IC}_{50}$ for the inhibition of nitric oxide production at $3 \mu \mathrm{M}$ and TNF- $\alpha$ production at $6.5 \mu \mathrm{M}$. Among the diterpenoids from the stems and twigs of the Chinese mangrove plant, Excoecaria agallocha, agallochaol $\mathrm{O}$ (Figure 2) at $100 \mu \mathrm{M}$ showed $52.6 \%$ inhibition of interleukin-6 (IL-6) and other proinflammatory cytokines induced by lipopolysaccharide (LPS) [15]. Bio-assay guided phytochemical investigation of Ipomoea-pes-caprae resulted in the isolation of eugenol (Figure 3), a well-known analgesic, anti-inflammatory natural product [31, 33]. Some studies resulted in the isolation of steroids and triterpenes as the active compounds (Table 3) [32].

Plants often produce secondary metabolites under stressful conditions. Therefore, it is not surprising that mangrove plants, facing various ecological and environmental stresses, biosynthesise a wide range secondary metabolites of potential medicinal importance. The present literature survey has revealed that mangrove plants contain a wide range 
TABLE 2: Antinociceptive, anti-inflammatory, and antipyretic activity of mangrove plant species.

\begin{tabular}{|c|c|c|c|c|c|c|}
\hline No & Plant name & Family & Plant part tested & Observed activity & Test method & Refs \\
\hline 1 & Acanthus hirsutus Boiss. & \multirow{2}{*}{ Acanthaceae } & Aqueous extract & Antinociceptive & Acetic-acid-induced in mice & {$[4]$} \\
\hline 2 & Acanthus ilicifolius Linn. & & $\begin{array}{l}\mathrm{MeOH} \text { fraction of } \\
\text { leaf extract }\end{array}$ & Anti-inflammatory & $\begin{array}{l}\text { Carrageenan-induced rat paw oedema, } \\
\text { COX ( } 1 \text { and } 2) \text { and 5-LOX activity }\end{array}$ & {$[5]$} \\
\hline 3 & $\begin{array}{l}\text { Aegiceras corniculatum } \\
\text { (Linn.) Blanco. }\end{array}$ & \multirow[b]{2}{*}{ Myrsinaceae } & $\begin{array}{l}n \text {-Hexane, EtOAc } \\
\text { and } \mathrm{MeOH} \text { extracts } \\
\text { of stem }\end{array}$ & $\begin{array}{l}\text { Antinociceptive, } \\
\text { Anti-inflammatory }\end{array}$ & $\begin{array}{l}\text { Acetic-acid-induced, } \\
\text { formalin-induced paw licking and hot } \\
\text { plate test in mice }\end{array}$ & {$[6]$} \\
\hline 4 & $\begin{array}{l}\text { Aegiceras corniculatum } \\
\text { (Linn.) Blanco. }\end{array}$ & & $\begin{array}{l}\text { MeOH extract of } \\
\text { stem }\end{array}$ & Anti-inflammatory & $\begin{array}{l}\text { Rat paw oedema and peritonitis } \\
\text { models were employed for in vivo } \\
\text { studies. For in vitro studies, human } \\
\text { platelets and rat neutrophils were } \\
\text { stimulated with } \mathrm{Ca}(2+) \text {-ionophore } \\
\text { A23187 leading to the production of } \\
\text { various proinflammatory metabolites, } \\
\text { that is, 12-HTT, 12-HETE and LTB(4), } \\
\text { and 5-HETE }\end{array}$ & {$[7]$} \\
\hline 5 & $\begin{array}{l}\text { Avicennia officinalis } \\
\text { Linn. }\end{array}$ & Avicenniaceae & $\begin{array}{l}\text { MeOH extract of } \\
\text { leaves }\end{array}$ & Anti-inflammatory & $\begin{array}{l}\text { Freunds adjuvant-induced arthritis, } \\
\text { carrageenan-, and formalin-induced } \\
\text { rat paw oedema }\end{array}$ & {$[8]$} \\
\hline 6 & $\begin{array}{l}\text { Barringtonia racemosa } \\
\text { Linn. }\end{array}$ & \multirow[t]{2}{*}{ Lecythidaceae } & $\begin{array}{l}98 \% n-\text { Hexane, } 98 \% \\
\mathrm{CHCl}_{3} \text { and } 95 \% \\
\text { EtOH extracts of leaf }\end{array}$ & Anti-inflammatory & $\begin{array}{l}\text { Inhibition of nitric oxide formation in } \\
\text { RAW } 264.7 \text { cells by Griess assay } \\
\text { Amount of lipid peroxidation by ferric } \\
\text { thiocyanate method }\end{array}$ & {$[9]$} \\
\hline 7 & $\begin{array}{l}\text { Barringtonia racemosa } \\
\text { Linn. }\end{array}$ & & $\begin{array}{l}\text { Aqueous bark } \\
\text { extract }\end{array}$ & Antinociceptive & $\begin{array}{l}\text { Tail flick, hot plate, and formalin tests } \\
\text { in rat }\end{array}$ & {$[10]$} \\
\hline 8 & $\begin{array}{l}\text { Caesalpinia mimosoides } \\
\text { Lamk. }\end{array}$ & Leguminosae & $\begin{array}{l}\mathrm{CH}_{2} \mathrm{Cl}_{2} \text { and acetone } \\
\text { extracts, pure } \\
\text { compounds }\end{array}$ & Anti-inflammatory & $\begin{array}{l}\text { Inhibition of lipopolysaccharide (LPS) } \\
\text { induced nitric oxide (NO) production } \\
\text { in RAW } 264.7 \text { cell lines }\end{array}$ & {$[11]$} \\
\hline 9 & $\begin{array}{l}\text { Ceriops decandra (Griff.) } \\
\text { W. Theob. }\end{array}$ & Rhizophoraceae & $\begin{array}{l}\text { EtOH extract of leaf } \\
\text { and pneumatophore }\end{array}$ & Antinociceptive & Acetic-acid-induced in mice & [12] \\
\hline 10 & $\begin{array}{l}\text { Calophyllum inophyllum } \\
\text { Linn. }\end{array}$ & \multirow{2}{*}{ Clusiaceae } & $\begin{array}{l}\text { EtOH extract of nut } \\
\text { kernel }\end{array}$ & Anti-inflammatory & $\begin{array}{l}\text { Carrageenan- and formalin-induced } \\
\text { rat paw oedemas, cotton pellet } \\
\text { implantation }\end{array}$ & [13] \\
\hline 11 & $\begin{array}{l}\text { Calophyllum inophyllum } \\
\text { Linn. }\end{array}$ & & $\begin{array}{l}\text { (Pure compounds } \\
\text { tested) }\end{array}$ & Anti-inflammatory & $\begin{array}{l}\text { Carrageenan-induced hind paw } \\
\text { oedema, cotton pellet granuloma and } \\
\text { granuloma pouch techniques, in } \\
\text { normal and adrenalectomized rats }\end{array}$ & {$[14]$} \\
\hline 12 & $\begin{array}{l}\text { Excoecaria agallocha } \\
\text { Linn. }\end{array}$ & Euphorbiaceae & $\begin{array}{l}\text { (Pure compounds } \\
\text { tested) }\end{array}$ & Anti-inflammatory & $\begin{array}{l}\text { Suppression of the expression of } \\
\text { NF- } \kappa \text { B and AP- } 1 \text { targeted genes } \\
\text { including TNF-alpha- and } \\
\text { IL-6-induced by lipopolysaccharide } \\
\text { (LPS) in mouse macrophages Raw } \\
264.7 \text { cells }\end{array}$ & [15] \\
\hline 13 & Nypa fruticans Wurmb. & Arecaceae & $\begin{array}{l}\mathrm{MeOH} \text { extract of } \\
\text { leaf and stem }\end{array}$ & Antinociceptive & Acetic-acid-induced in mice & {$[16]$} \\
\hline 14 & Pandanus foetidus Roxb. & Pandanaceae & $\begin{array}{l}\text { MeOH extract of } \\
\text { leaf }\end{array}$ & Antinociceptive & Acetic-acid-induced in mice & {$[17]$} \\
\hline 15 & $\begin{array}{l}\text { Pongamia pinnata }(\mathrm{L} .) \\
\text { Pierre }\end{array}$ & \multirow[b]{2}{*}{ Fabaceae } & $\begin{array}{l}70 \% \text { EtOH extract } \\
\text { of leaf }\end{array}$ & $\begin{array}{l}\text { Antinociceptive } \\
\text { and antipyretic } \\
\text { activity }\end{array}$ & $\begin{array}{l}\text { Hotplate and tail flick, acetic acid } \\
\text { writhing and Randall-Selitto } \\
\text { nociceptive tests in mice and brewer's } \\
\text { yeast-induced pyrexia in rats }\end{array}$ & [18] \\
\hline 16 & $\begin{array}{l}\text { Pongamia pinnata }(\mathrm{L} .) \\
\text { Pierre }\end{array}$ & & $\begin{array}{l}70 \% \text { EtOH extract } \\
\text { of leaf }\end{array}$ & Anti-inflammatory & $\begin{array}{l}\text { Carrageenin, histamine, } \\
\text { 5-hydroxytryptamine and } \\
\text { prostaglandin E-2-induced hind paw } \\
\text { edema, kaolin-carrageenan and } \\
\text { formaldehyde-induced hind paw } \\
\text { oedema, cotton pellet granuloma } \\
\text { models of inflammation }\end{array}$ & [19] \\
\hline
\end{tabular}


TABle 2: Continued.

\begin{tabular}{|c|c|c|c|c|c|c|}
\hline No & Plant name & Family & Plant part tested & Observed activity & Test method & Refs \\
\hline 17 & $\begin{array}{l}\text { Pongamia pinnata }(\mathrm{L} .) \\
\text { Pierre }\end{array}$ & & $\begin{array}{l}70 \% \text { EtOH extract of } \\
\text { seed }\end{array}$ & $\begin{array}{l}\text { Antinociceptive, } \\
\text { Anti-inflammatory }\end{array}$ & $\begin{array}{l}\text { Carrageenan-induced hind paw } \\
\text { oedema and Randall-Selitto } \\
\text { nociceptive test in rat }\end{array}$ & [20] \\
\hline 18 & $\begin{array}{l}\text { Pongamia pinnata }(\mathrm{L} .) \\
\text { Pierre }\end{array}$ & & $\begin{array}{l}\mathrm{PE}, \mathrm{CHCl}_{3} \text {, acetone } \\
\text { and } \mathrm{EtOH} \text { extracts of } \\
\text { seed }\end{array}$ & $\begin{array}{l}\text { Antinociceptive, } \\
\text { Anti-inflammatory }\end{array}$ & & [21] \\
\hline 19 & $\begin{array}{l}\text { Pongamia pinnata }(\mathrm{L} .) \\
\text { Pierre }\end{array}$ & & $\begin{array}{l}70 \% \mathrm{EtOH} \text { extract of } \\
\text { seed }\end{array}$ & Anti-inflammatory & $\begin{array}{l}\text { Bradykinin and PGE-1-induced } \\
\text { inflammation, histamine and } \\
\text { 5-HT-induced inflammation }\end{array}$ & [22] \\
\hline 20 & Tamarix indica Willd. & Tamaricaceae & $\begin{array}{l}80 \% \mathrm{MeOH} \text { extract of } \\
\text { root }\end{array}$ & $\begin{array}{l}\text { Antinociceptive, } \\
\text { Anti-inflammatory }\end{array}$ & $\begin{array}{l}\text { Acetic-acid-induced in mice, using } \\
\text { carrageenan induced rat paw oedema }\end{array}$ & [23] \\
\hline 21 & $\begin{array}{l}\text { Derris scandens (Roxb.) } \\
\text { Benth. }\end{array}$ & Fab & $\begin{array}{l}\mathrm{CHCl}_{3} \text { extracts of leaf } \\
\text { and root and pure } \\
\text { compounds }\end{array}$ & Anti-inflammatory & $\begin{array}{l}\text { Carrageenan-induced paw oedema in } \\
\text { rats }\end{array}$ & [24] \\
\hline 22 & $\begin{array}{l}\text { Derris scandens (Roxb.) } \\
\text { Benth. }\end{array}$ & & $\begin{array}{l}\text { Aqueous extract of } \\
\text { stem and pure } \\
\text { compounds }\end{array}$ & Anti-inflammatory & Eicosanoid inhibition & [25] \\
\hline 23 & $\begin{array}{l}\text { Ipomoea imperati (Vahl) } \\
\text { Griseb. }\end{array}$ & & $\begin{array}{l}\text { EtOH extract of } \\
\text { whole plant }\end{array}$ & Antinociceptive & $\begin{array}{l}\text { Acetic-acid-induced and hot plate test } \\
\text { in mice }\end{array}$ & [26] \\
\hline 24 & $\begin{array}{l}\text { Ipomoea imperati (Vahl) } \\
\text { Griseb. }\end{array}$ & & $\begin{array}{l}\text { MeOH-water extract } \\
\text { of leaf }\end{array}$ & Anti-inflammatory & $\begin{array}{l}\text { Mouse ear oedema induced by croton } \\
\text { oil, arachidonic acid, cotton } \\
\text { pellet-induced granulomas, inhibition } \\
\text { of Phospholipase } \mathrm{A}(2) \text { purified from } \\
\text { Apis mellifera bee venom }\end{array}$ & {$[27]$} \\
\hline 25 & $\begin{array}{l}\text { Ipomoea pes-caprae (L.) } \\
\text { R-Br. }\end{array}$ & Convolvulaceae & $\begin{array}{l}\mathrm{MeOH} \text { extract and } \\
\text { two fractions of aerial } \\
\text { part }\end{array}$ & Antinociceptive & $\begin{array}{l}\text { Acetic-acid-induced and formalin test } \\
\text { in mice }\end{array}$ & [28] \\
\hline 26 & $\begin{array}{l}\text { Ipomoea pes-caprae (L.) } \\
\text { R-Br. }\end{array}$ & & Pure compounds & Antinociceptive & $\begin{array}{l}\text { Acetic-acid-induced and formalin test } \\
\text { in mice }\end{array}$ & [29] \\
\hline 27 & $\begin{array}{l}\text { Ipomoea pes-caprae (L.) } \\
\text { R-Br. }\end{array}$ & & $\begin{array}{l}\text { Crude extract and } \\
\text { pure compounds }\end{array}$ & Anti-inflammatory & $\begin{array}{l}\text { Inhibition of prostaglandin synthesis } \\
\text { in vitro }\end{array}$ & [30] \\
\hline 28 & $\begin{array}{l}\text { Ipomoea pes-caprae (L.) } \\
\text { R-Br. }\end{array}$ & & Crude extract & Anti-inflammatory & $\begin{array}{l}\text { Carrageenan-induced paw oedema } \\
\text { and ear oedema induced in rats by } \\
\text { arachidonic acid or ethyl } \\
\text { phenylpropiolate, inhibition of } \\
\text { prostaglandin synthesis in vitro }\end{array}$ & {$[31]$} \\
\hline 29 & Heritiera littoralis Aiton & Sterculiaceae & Pure compounds & Anti-inflammatory & $\begin{array}{l}\text { Nitric oxide (NO) inhibitory effects } \\
\text { using RAW } 264.7 \text { macrophage cells }\end{array}$ & {$[32]$} \\
\hline
\end{tabular}

TABle 3: Analgesic, anti-inflammatory compounds from mangrove plants.

\begin{tabular}{ll}
\hline No & Pure compound related to the observed activity \\
\hline 5 & The anti-inflammatory activity of methanolic extract of Avicennia officinalis may be due to the \\
presence of the phytoconstituent, betulinic acid & Rimosol D, taepeenin D, taepeenin L, $(E)$-7-hydroxy-3-(4-methoxybenzyl)chroman-4-one, \\
& $(E)-7,8$-dihydroxy-3-(4-methoxybenzyl)chroman-4-one, \\
& $(E)-7$-hydroxy-8-methoxy-3-(4-methoxybenzyl)chroman-4-one \\
& Calophyllolide \\
10 & Dehydrocycloguanandin and calophyllin-B \\
11 & Agallochaol K, agallochaol O, agallochaol P, agallochaol Q, ent-17-hydroxykaur-15-en-3-one, \\
12 & ent-kaur-15-en-3b,17-diol, ent-15,18-dihydroxylabd-8,13E-diene \\
21 & Ovaliflavanone and lupinifolin \\
22 & $3-\gamma, \gamma$-dimethylallylweighteone, scandenin and genistein \\
26 & Glochidone, betulinic acid, $\alpha$-amyrin acetate, $\beta$-amyrin acetate, isoquercitrin \\
27 & Eugenol and 4-vinyl-guaiacol \\
29 & Ergosterol peroxide, 6- $\alpha$-hydroxystigmast-4-en-3-one and stigmast-4-en-3-one
\end{tabular}




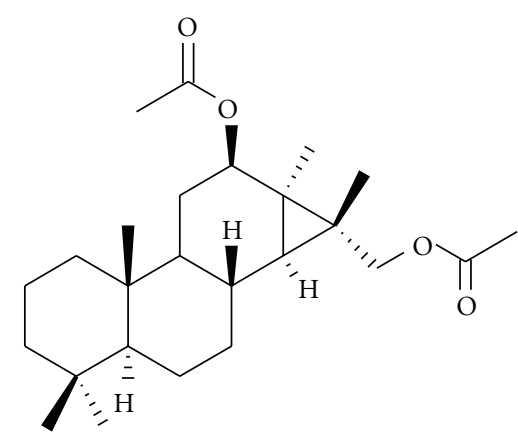

Figure 1: Mimosol D, an anti-inflammatory diterpene from the roots of Caesalpinia mimosoides.

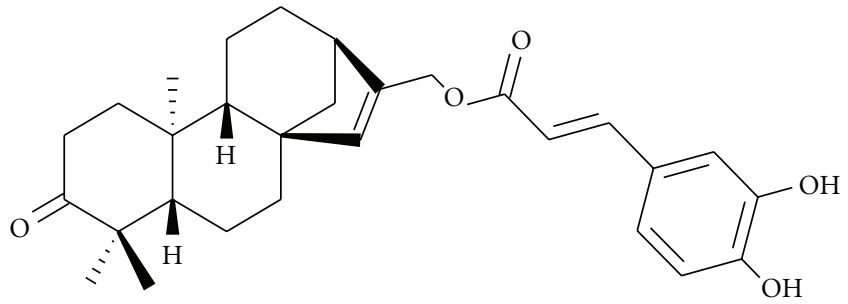

Figure 2: Agallochaol O, an anti-inflammatory diterpene from the stems and twigs of Excoecaria agallocha.

of compounds showing antinociceptive, anti-inflammatory and or antipyretic activity (Tables 2 and 3 ).

Pain itself is not any disease. It is manifested in certain disease or pathological conditions. Use of natural products in the management of pain goes back to thousands of years. Use of poppy by various civilizations or the use of willow bark to cure fever led to the isolation of morphine and salicylic acid, respectively [34]. These two drugs are still used extensively in modern medical practice. Present trend of the researchers to focus on mangrove plants has opened up an arena to find bioactive compounds from a source that has long been ignored or less explored. It is expected that research on mangrove plants will continue to rise in the coming days.

\section{Possible Mechanism of Actions}

It must be stressed that there are no or a few reports available on the possible mechanisms of action of the extracts or isolated compounds from the mangrove plants. However, exploring the methods applied in the published reports on evaluation of antinociceptive, anti-inflammatory, and/or antipyretic activity of mangrove plants [4-34], the following assumptions can be made about the possible mechanisms of actions. The sensation of pain can be initiated either peripherally or through the central nervous system. Peripherally mediated pain can be inhibited by NSAIDs which blocks the anti-inflammatory pathways responsible for pain. On the other hand, opioid analgesics are useful for the management of centrally acting pain in which opioid analgesics act by inhibition of opioid receptors. Acetic-acid-induced and formalin-induced paw licking represents peripherally acting pain sensation. Intraperitoneal administration of acetic acid<smiles>C=CCc1ccc(O)c(OC)c1</smiles>

FIGURE 3: Eugenol, an analgesic and anti-inflammatory compound, from Ipomoea-pes-caprae.

or formalin mediates pain response through the release of inflammatory mediators, mainly prostacycline $\left(\mathrm{PGI}_{2}\right)$ [35, 36]. The hot plate test, the tail flick test, and the RandallSelitto nociceptive test represent nociception through central mechanism [35, 37]. The rat paw oedema is an antiinflammatory model that can be induced by carrageenan, formalin, kaolin, cotton pellet granuloma and granuloma, pouch. Inflammation of the rat paw can also be stimulated by administration of inflammatory mediators like histamine, or eicosanoids like 5-hydroxytryptamine and prostaglandin E-2 [22, 25]. Other anti-inflammatory models that have been used in the assessment include nitric oxide, TNF- $\alpha$, and IL6 induction by the administration of lipopolysaccharides in cell culture [14].

A wide range of methods were adopted by different research groups for the study of antinociceptive activity of mangrove plants. All these methods can be summed up to two major mechanisms, that is, centrally acting and peripherally mediated pain sensation. Different mangrove plants were able to inhibit pain sensation of both types. Therefore, it is possible to find opioid analgesics as well as analgesics in mangrove plants that act by inhibition of inflammatory pathways responsible for pain. Only in few cases, plants were investigated by methods that represent both of the mechanisms. Interestingly, articles that report the isolation of active compounds used methods representing peripherally acting pain sensation.

\section{Conclusions}

This review has revealed that antinociceptive, antiinflammatory, and antipyretic activity appears to be widespread among mangrove plants, and thorough and systematic phytochemical and pharmacological studies are much needed to discover new antinociceptive, antiinflammatory, and antipyretic medicinal entities from mangrove plants.

\section{Acknowledgment}

A part of this study was supported by an INSPIRE grant (no. SP_137, 2011-2013) from the British Council.

\section{References}

[1] D. M. Alongi, "Present state and future of the world's mangrove forests," Environmental Conservation, vol. 29, no. 3, pp. 331-349, 2002.

[2] M. Spalding, F. Blasco, and C. Field, World Mangrove Atlas, The International Society for Mangrove Ecosystems, Okinawa, Japan, 1997. 
[3] S. Sarker, K. C. Kuri, M. S. M. Chowdhury, and M. T. Rahman, "Mangrove: a livelihood option for coastal community of Bangladesh," Bangladesh Research Publications Journal, vol. 3, no. 4, pp. 1187-1192, 2010.

[4] U. S. Harput, O. Arihan, A. B. Iskit, A. Nagatsu, and I. Saracoglu, "Antinociceptive, free radical-scavenging, and cytotoxic activities of Acanthus hirsutus Boiss," Journal of Medicinal Food, vol. 14, no. 7-8, pp. 767-774, 2011.

[5] M. S. Kumar, B. Gorain, D. K. Roy et al., "Anti-inflammatory activity of Acanthus ilicifolius," Journal of Ethnopharmacology, vol. 120, no. 1, pp. 7-12, 2008.

[6] T. Roome, A. Dar, and A. Naqvi, "Evaluation of antinociceptive effect of Aegiceras corniculatum stems extracts and its possible mechanism of action in rodents," Journal of Ethnopharmacology, vol. 135, no. 2, pp. 351-358, 2011.

[7] T. Roome, A. Dar, S. Naqvi, S. Ali, and M. I. Choudhary, "Aegiceras corniculatum extract suppresses initial and late phases of inflammation in rat paw and attenuates the production of eicosanoids in rat neutrophils and human platelets," Journal of Ethnopharmacology, vol. 120, no. 2, pp. 248-254, 2008.

[8] M. Sumithra, V. K. Janjanam, and V. S. Kancharana, "Influence of methanolic extract of Avicennia officinalis leaves on acute, subacute and chronic inflammatory models," International Journal of PharmTech Research, vol. 3, no. 2, pp. 763-768, 2011.

[9] M. Behbahani, A. M. Ali, R. Muse, and N. B. Mohd, "Anti-oxidant and anti-inflammatory activities of leaves of Barringtonia racemosa," Journal of Medicinal Plants Research, vol. 1, no. 5, pp. 95-102, 2011.

[10] S. A. Deraniyagala, W. D. Ratnasooriya, and C. L. Goonasekara, "Antinociceptive effect and toxicological study of the aqueous bark extract of Barringtonia racemosa on rats," Journal of Ethnopharmacology, vol. 86, no. 1, pp. 21-26, 2003.

[11] O. Yodsaoue, C. Karalai, C. Ponglimanont, S. Tewtrakul, and S. Chantrapromma, "Potential anti-inflammatory diterpenoids from the roots of Caesalpinia mimosoides Lamk," Phytochemistry, vol. 71, no. 14-15, pp. 1756-1764, 2010.

[12] S. J. Uddin, J. A. Shilpi, J. Barua, and R. Rouf, "Antinociceptive activity of Ceriops decandra leaf and pneumatophore," Fitoterapia, vol. 76, no. 2, pp. 261-263, 2005.

[13] T. N. Bhalla, R. C. Saxena, S. K. Nigam, G. Misra, and K. P. Bhargava, "Calophyllolide: a new non-steroidal antiinflammatory agent," Indian Journal of Medical Research, vol. 72, no. 5, pp. 762-765, 1980.

[14] C. Gopalakrishnan, D. Shankaranarayanan, and S. K. Nazimudeen, "Anti inflammatory and central nervous system depressant activities of xanthones from Calophyllum inophyllum and Mesua ferrea," Indian Journal of Pharmacology, vol. 12, no. 3, pp. 181-192, 1980.

[15] Y. Li, J. Liu, S. Yu, P. Proksch, J. Gu, and W. Lin, "TNF$\alpha$ inhibitory diterpenoids from the Chinese mangrove plant Excoecaria agallocha L," Phytochemistry, vol. 71, no. 17-18, pp. 2124-2131, 2010.

[16] H. Reza, W. M. Haq, A. K. Das, S. Rahman, R. Jahan, and M. Rahmatullah, "Anti-hyperglycemic and antinociceptive activity of methanol leaf and stem extract of Nypa Fruticans Wurmb," Pakistan Journal of Pharmaceutical Sciences, vol. 24, no. 4, pp. 485-488, 2011.

[17] S. J. Uddin, J. A. Shilpi, M. T. Rahman, M. Ferdous, R. Rouf, and S. D. Sarker, "Assessment of neuropharmacological activities of Pandanus foetidus (Pandanaceae) in mice," Pharmazie, vol. 61, no. 4, pp. 362-364, 2006.
[18] K. Srinivasan, S. Muruganandan, J. Lal et al., "Antinociceptive and antipyretic activities of Pongamia pinnata leaves," Phytotherapy Research, vol. 17, no. 3, pp. 259-264, 2003.

[19] K. Srinivasan, S. Muruganandan, J. Lal, S. Chandra, S. K. Tandan, and V. Ravi Prakash, "Evaluation of anti-inflammatory activity of Pongamia pinnata leaves in rats," Journal of Ethnopharmacology, vol. 78, no. 2-3, pp. 151-157, 2001.

[20] S. Muruganandan, K. Srinivasan, S. K. Tandan, J. Lal, S. Chandra, and V. Raviprakash, "Anti-inflammatory and antinociceptive activities of some medicinal plants," Journal of Medicinal and Aromatic Plant Sciences, vol. 22-23, no. 4A-1A, pp. 56-58, 2000.

[21] R. K. Singh, V. K. Joshi, R. K. Goel, S. S. Gambhir, and S. B. Achaiya, "Pharmacological actions of Pongamia pinnata seeds-a preliminary study," Indian Journal of Experimental Biology, vol. 34, no. 12, pp. 1204-1207, 1996.

[22] R. K. Singh and B. L. Pandey, "Anti-inflammatory activity of seed extracts of Pongamia pinnata in rat," Indian Journal of Physiology and Pharmacology, vol. 40, no. 4, pp. 355-358, 1996.

[23] M. A. Rahman, E. Haque, M. Hasanuzzaman, and I. Z. Shahid, "Antinociceptive, antiinflammatory and antibacterial properties of Tamarix indica roots," International Journal of Pharmacology, vol. 7, no. 4, pp. 527-531, 2011.

[24] S. Ganapaty, J. S. Josaphine, and P. S. Thomas, "Antiinflammatory activity of Derris scandens," Journal of Natural Remedies, vol. 6, no. 1, pp. 73-76, 2006.

[25] P. Laupattarakasem, P. J. Houghton, and J. R. S. Hoult, "Anti-inflammatory isoflavonoids from the stems of Derris scandens," Planta Medica, vol. 70, no. 6, pp. 496-501, 2004.

[26] A. C. B. De Paula-Zurron, N. M. M. A. Petraglia, C. R. Aur et al., "Antinociceptive activity of Ipomoea imperati (Vahl) Griseb., Convolvulaceae," Revista Brasileira de FarmacognosiaBrazilian Journal of Pharmacognosy, vol. 20, no. 2, pp. 180-185, 2010.

[27] A. C. B. Paula, L. S. S. Hayashi, and J. C. Freitas, "Antiinflammatory and antispasmodic activity of Ipomoea imperati (Vahl) Griseb (Convolvulaceae)," Brazilian Journal of Medical and Biological Research, vol. 36, no. 1, pp. 105-112, 2003.

[28] M. M. de Souza, A. Madeira, C. Berti, R. Krogh, R. A. Yunes, and V. Cechinel, "Antinociceptive properties of the methanolic extract obtained from Ipomoea pes-caprae (L.) R. Br," Journal of Ethnopharmacology, vol. 69, no. 1, pp. 85-90, 2000.

[29] R. Krogh, R. Kroth, C. Berti et al., "Isolation and identification of compounds with antinociceptive action from Ipomoea pescaprae (L.) R. Br," Pharmazie, vol. 54, no. 6, pp. 464-466, 1999.

[30] U. Pongprayoon, P. Baeckstrom, U. Jacobsson, M. Lindstrom, and L. Bohlin, "Compounds inhibiting prostaglandin synthesis isolated from Ipomoea pes-caprae," Planta Medica, vol. 57, no. 6, pp. 515-518, 1991.

[31] U. Pongprayoon, L. Bohlin, P. Soonthornsaratune, and S. Wasuwat, "Antiinflammatory activity of Ipomoea pes-caprae (L.) R. Br," Phytotherapy Research, vol. 5, no. 2, pp. 63-66, 1991.

[32] S. Tewtrakul, P. Tansakul, C. Daengrot, C. Ponglimanont, and C. Karalai, "Anti-inflammatory principles from Heritiera littoralis bark," Phytomedicine, vol. 17, no. 11, pp. 851-855, 2010.

[33] K. Pramod, S. H. Ansari, and J. Ali, "Eugenol: a natural compound with versatile pharmacological actions," Natural Product Communications, vol. 5, no. 12, pp. 1999-2006, 2010.

[34] W. Sneader, Drug Discovery: A History, John Wiley \& Sons, England, UK, 2005. 
[35] M. T. Rahman, J. A. Shilpi, M. Ahmed, and C. F. Hossain, "Preliminary pharmacological studies on Piper chaba stem bark," Journal of Ethnopharmacology, vol. 99, no. 2, pp. 203209, 2005.

[36] E. Elisabetsky, T. A. Arnador, R. R. Albuquerque, D. S. Nunes, and A. D. T. Carvalho, "Analgesic activity of Psychotria colorata (Willd. ex R. and S.) Muell. Arg. alkaloids," Journal of Ethnopharmacology, vol. 48, no. 2, pp. 77-83, 1995.

[37] X. G. Dong and L. C. Yu, "Alterations in the substance Pinduced anti-nociception in the central nervous system of rats after morphine tolerance," Neuroscience Letters, vol. 381, no. 1-2, pp. 47-50, 2005. 

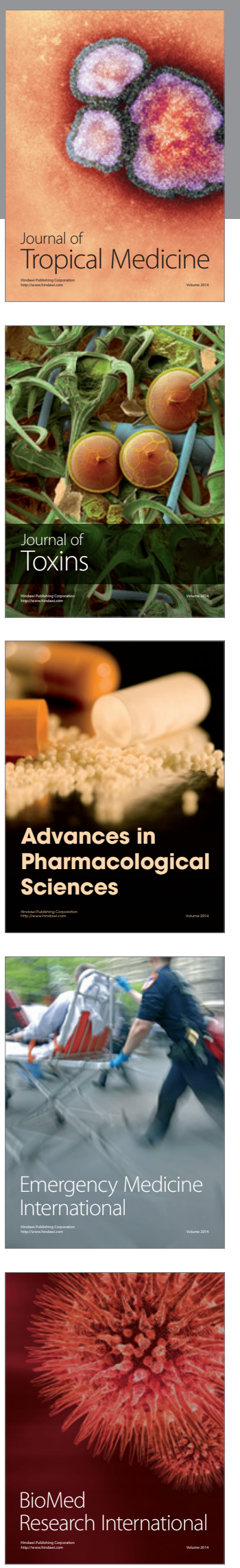
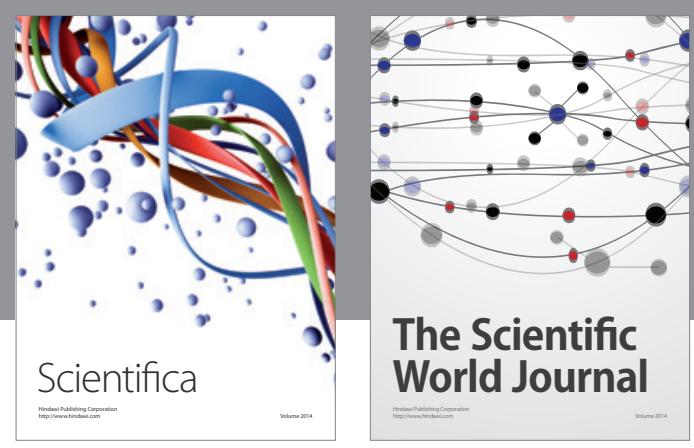

The Scientific World Journal
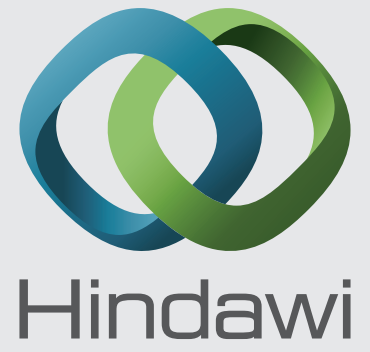

Submit your manuscripts at

http://www.hindawi.com
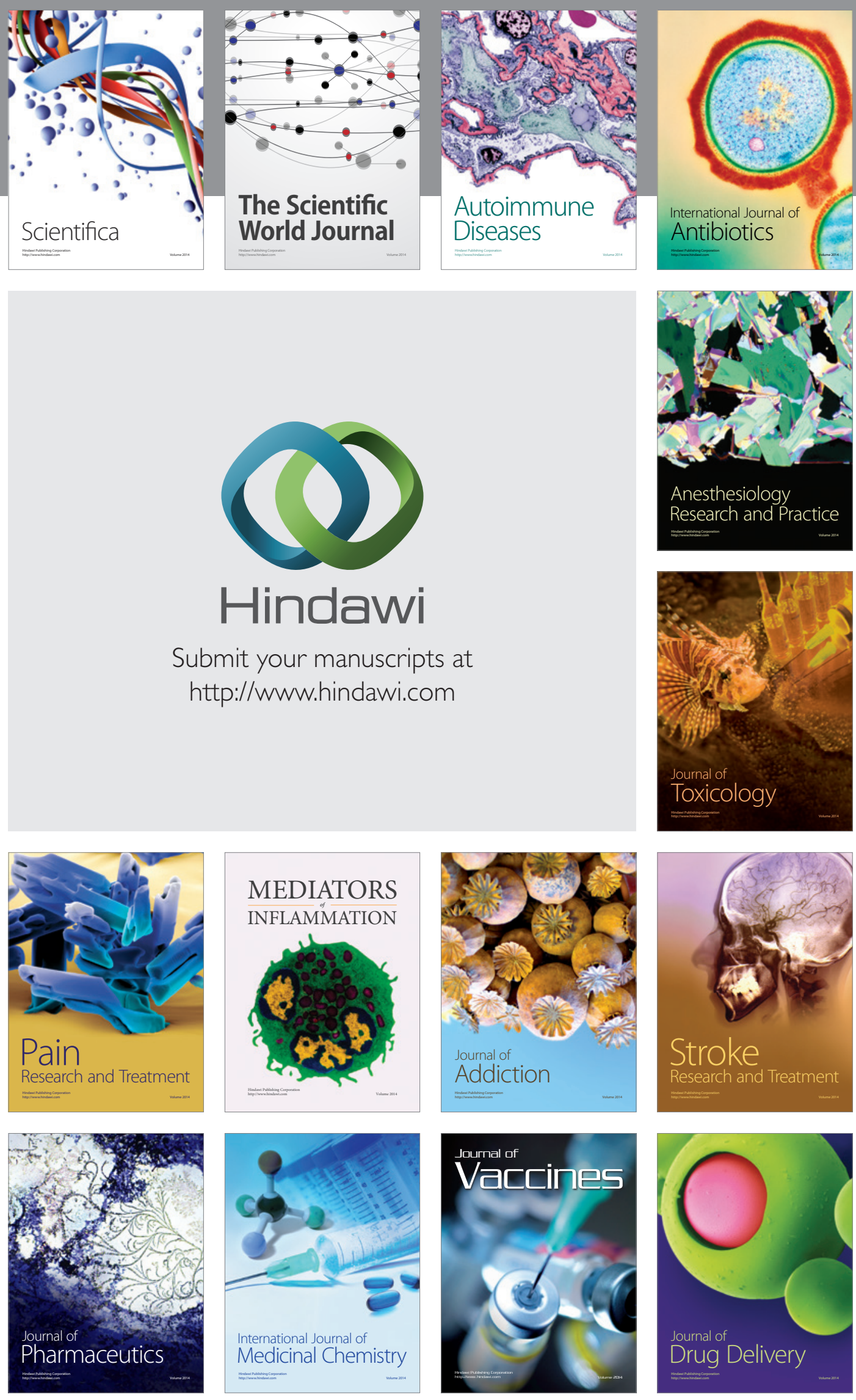